\title{
Memória e Patrimônio: a Questão do valor Histórico das ARMAS DE FOgO ENTREgUES NA CAMPANHA DE DESARMAMENTO
}

Dyêgo Marinho Martins

Departamento de Polícía Federal - Brasil

$\approx$

\begin{abstract}
RESUMO
Pesquisa centrada na análise da problemática acerca dos critérios adotados para a definição do valor histórico das armas de fogo antigas e obsoletas, entregues na Campanha Nacional de Desarmamento, instituída no âmbito da Lei Federal n 10.826/2003 (Estatuto do Desarmamento). Através da discussão sobre o regulamento atualmente em vigência, pretende-se demonstrar a ausência de um padrão confiável para a definição do valor histórico. Para tanto, é apresentada a sistemática adotada pela National Rifle Association, que considera variáveis tais como significação histórica e credibilidade, associadas a fatores como oportunidade, pronta identificação e credibilidade da fonte. Por fim, discute-se como a ausência de uma norma detalhada sobre o tema indica o descuido com a preservação da memória nacional e leva à destruição das armas de fogo que constituem o patrimônio histórico brasileiro.
\end{abstract}

Palavras-chave: Desarmamento. Polícia Federal. Exército Brasileiro. Armas de Fogo. Patrimônio Histórico.

\section{INTRODUÇÃ̃o}

O presente artigo tem como objetivo problematizar os critérios e procedimentos em vigência adotados pelos órgãos legalmente competentes na definição do valor histórico das armas de fogo entregues na Campanha Nacional de Desarmamento. Ao longo do texto, serão feitas considerações acerca dos dispositivos legais adotados atualmente pelos referidos órgãos (Exército e Polícia Federal) e de como a ausência de critérios bem definidos e procedimentos adequados causam prejuízos à avaliação do valor histórico das armas, tendo como consequência a destruição de bens que constituem o patrimônio histórico nacional.

A Campanha Nacional de Desarmamento, em vigor no Brasil desde 2004, já recolheu mais de quatrocentas e sessenta mil armas, entregues 
voluntariamente pelos detentores e proprietários, nas unidades do Departamento de Polícia Federal e postos credenciados. Instituída no âmbito a Lei $\mathrm{n}^{\circ} 10.826 / 2003$ (Estatuto do Desarmamento), a iniciativa busca estimular a entrega voluntária mediante indenização, tendo como base o pressuposto de retirar das ruas parte considerável do armamento de circulação, contribuindo com a redução dos índices de mortes por armas de fogo no País.

No decorrer da campanha foram feitos questionamentos sobre a destinação das armas de fogo que, pela legislação vigente, após serem arrecadadas pela Polícia Federal, devem ser destruídas pelo Exército Brasileiro. Tais questionamentos versam sobre a possibilidade de armas de fogo de valor histórico terem sido inutilizadas e destruídas indiscriminadamente, o que levou, em julho de 2010, ao julgamento de Ação Civil Pública, com pedido de tutela antecipada (Processo no 0011559-16.2010.403.6100).

A ação foi interposta pelo Instituto do Patrimônio Histórico - IPH, em face da União Federal, no sentido de que a ré se abstivesse de agir conforme o disposto no artigo $70-E$ do Decreto $n^{\circ} 5.123 / 2004^{1}$. Para tanto, a União deveria interromper a destruição das armas de fogo entregues na Campanha de Desarmamento, tendo em vista "o princípio da supremacia constitucional, no tocante a proteção ao patrimônio histórico e cultural” (BRASIL, 2010a, p. 01).

Nas seções seguintes discutiremos os desdobramentos da ação interposta pelo IPH, que resultaram na edição, pela Polícia Federal, de um documento que pudesse fornecer aos servidores das unidades nas quais o recebimento das armas é processado, orientações sobre quais procedimentos adotar no caso da entrega de armas que possam ser classificadas como dotadas de valor histórico. A intenção é discutir a precariedade da norma vigente, com base na comparação entre a norma adotada e outros sistemas reconhecidos internacionalmente, aptos a servir como base para o estabelecimento de um padrão brasileiro para aferição do valor histórico das armas de fogo.

1 Art. 70-E. As armas de fogo entregues na campanha do desarmamento não serão submetidas a perícia, salvo se estiverem com o número de série ilegível ou houver dúvidas quanto à sua caracterização como arma de fogo, podendo, nesse último caso, serem submetidas a simples exame de constatação. Parágrafo único. As armas de fogo de que trata o caput serão, obrigatoriamente, destruídas. (Incluído pelo Decreto n 6.715, de 2008). 


\section{O Problema da Destruição das Armas de Fogo na Campanha de Desarmamento}

Inicialmente, cabe ressaltar que a ação proposta pelo IPH foi motivada pela divulgação de estatísticas oficiais segundo as quais, do início da campanha pública, em 2004, até o ano de 2010, cerca de quatrocentas e sessenta mil armas haviam sido apresentadas pela população à Polícia Federal (instituição responsável pelo recebimento), mediante indenização prevista pela Lei no 10.826/2003. Desse modo, o Exército Brasileiro, responsável pela destruição do armamento, continuava a inutilizar e destruir indiscriminadamente todas as armas de fogo recebidas até então, sem avaliar adequadamente aquelas dotadas de "valor histórico" e que constituiriam bens do patrimônio histórico nacional.

Na ocasião, a juíza federal Elisabeth Leão, da $12^{a}$ Vara Cível da capital paulista, decidiu pelo deferimento da tutela antecipada requerida na petição inicial. Na decisão, proferida em 10 de julho daquele ano, ficou determinado que as armas de fogo entregues na campanha permanecessem "acauteladas e conservadas, até decisão final" (BRASIL, 2010a, p. 01).

A magistrada ainda expediu duas intimações: a primeira delas, ao Ministério Público Federal, para que se manifestasse "sobre o requerimento de perícia às entidades públicas e privadas, para comprovar o valor cultural histórico das armas" (BRASIL, 2010a, p. 01). A segunda, ao Instituto Nacional do Patrimônio Histórico e Artístico Nacional (IPHAN), para que informasse ao Juízo sobre a existência de "interesse e condições para atestar o valor cultural histórico das armas entregues à Polícia Federal na Campanha do Desarmamento" (BRASIL, 2010a, p. 04).

Na análise do mérito da questão, a juíza destacou a obrigação constitucional do Poder Público, em conjunto com a comunidade, de promover o patrimônio cultural brasileiro por meio de formas de acautelamento e preservação. Em seguida, se referiu à existência de museus brasileiros e estrangeiros que se ocupam preservação dos bens que compõem patrimônio histórico cultural, dentre eles, as armas de fogo (BRASIL, 2010). 
Posteriormente, o desembargador federal Carlos Muta julgou o Agravo de Instrumento no 0027168-06.2010.4.03.0000 (Processo ${ }^{\circ}$ 2010.03.00.027168-0 SP), interposto contra a antecipação de tutela na Ação Civil Pública de proposta pelo IPH. No julgamento, o desembargador reformou em parte a decisão da 12a Vara Cível Federal de São Paulo, nos seguintes termos:

A relevância da proteção a tal patrimônio há de ser assegurada mediante avaliação criteriosa da própria União, a qual pode e deve, nos termos da legislação, promover a destinação, inclusive destruição, se for o caso, de todas as que se reputem modernas ou sem valor histórico-cultural, conservando apenas as de estrita e comprovada relevância para o bem jurídico em discussão na açãa civilpública (BRASIL, 2010b, p. 02).

Após a reforma parcial da decisão, o Departamento de Polícia Federal, por meio da Divisão de Repressão ao Tráfico Ilícito de Armas - DARM expediu o Memorando-Circular no 09/2011-DARM/DICOR/DPF. O documento estabeleceu os procedimentos a serem observados nas unidades responsáveis pelo recebimento quanto às armas consideradas de "valor histórico".

Mesmo antes da expedição do Memorando no 09/2011, a Polícia Federal já havia normatizado procedimentos para o recebimento de armas e munições na campanha, prevenindo as unidades policiais quanto à observância da decisão nos autos do Agravo de Instrumento no 0027168 06.2010.4.03.0000. Nesse sentido, o Ofício-Circular no 405/2011-CGPRE/DCOR/DPF, estabeleceu que, por força da decisão exarada, as "armas caracterizadas como de valor histórico ou obsoletas não devem ser inutilizadas no momento da entrega ou encaminhadas ao Exército Brasileiro para destruição" (BRASIL, 2011, p. 01).

Desse modo, estipulou-se que, inicialmente, as armas de fogo devem ser submetidas "a simples exame de constatação, instruído com fotos do armamento, onde se indiquem os elementos de convicção relacionados ao valor histórico verificado" (BRASIL, 2011, p. 03). Em seguida, as armas e os respectivos exames devem ser remetidos à unidade do Exército Brasileiro responsável pela destruição do armamento recebido na campanha, para fins de confirmação do valor histórico dos itens examinados. 
Ao Exército cabe, portanto, emitir avaliação final sobre o valor histórico e, em caso de confirmação, decidir pelo encaminhamento do item a museu, seguido do cadastramento no Sistema de Gerenciamento Militar de Armas - SIGMA. Caso a avaliação não confirme o valor histórico das peças, a Força deve providenciar a destruição do armamento.

O texto do Memorando $n^{\circ}$ 09/2011 chama atenção para os termos do art. 23 da Lei ${ }^{\circ} 10.826 / 2003$ c/c art. 60, parágrafo único, do Decreto $\mathrm{n}^{\circ} 5.123 / 2004$. Segundo tais dispositivos, os critérios para a definição do termo "valor histórico" devem ser estabelecidos pelo Comando do Exército, em norma específica, mediante proposta encaminhada ao Chefe do Poder Executivo Federal, que detém a competência para disciplinar o tema.

Não obstante o teor da norma, o memorando ressaltava que, até aquele momento, tal tema ainda não havia sido disciplinado. Diante do impasse, a Divisão de Repressão ao Tráfico Ilícito de Armas DARM, orientou as unidades policiais sobre a análise preliminar do valor histórico das armas de fogo entregues. Tal análise deve obedecer aos critérios constantes no Projeto de Lei ${ }^{\circ} 1782 / 07^{2}$, em tramitação na Câmara dos Deputados.

O referido projeto, de autoria da deputada federal Andreia Zito (PSDB$-\mathrm{RJ})^{3}$, propunha a alteração do Estatuto do Desarmamento, tornando isentas de registro, destruição e apreensão as armas de fogo obsoletas ou de valor histórico. Segundo a proposta, são consideradas armas de fogo de valor histórico:

(...) todas as armas com brasão ou inscrição Colonial, Imperial ou da República, ou qualquer sinal que indique seu uso oficial, inclusive em estados e municipios, ou aquelas que, mesmo sem estes, tenham sido empregadas pelas Forças Armadas ou Auxiliares do Brasil, ou tenham sido trazidas como troféus de guerra de hostilidades em que a Nação tenha participado, ou tenham participado de conflitos internos ou outros eventos da história do País ou, ainda tenham pertencido a personalidades históricas brasileiras ou estrangeiras (BRASIL, 2007, p. 01).

2 Tal orientação também consta no Manual de instruções para unidades credenciadas para receber armas de fogo, acessórios e munições, guia instrucional elaborado pela Coordenação Geral de Polícia de Repressão a Entorpecentes da Polícia Federal.

3 Conforme consulta na página da Câmara dos Deputados, o referido projeto de Lei tramita na Comissão de Constituição e Justiça e de Cidadania (CCJC), desde 08/09/2009. 
Por fim, o memorando sugere que as armas consideradas de valor histórico, após avaliação do Exército Brasileiro, em conjunto com a Polícia Federal, devem ser encaminhadas a museus das Forças Armadas ou de instituições policiais. A medida tomava como referência o procedimento quanto às armas de fogo apreendidas, conforme o disposto no art. $65, \S$ $1^{\circ}$ do Decreto n ${ }^{\circ} 5.123 / 2004^{4}$.

\section{Critérios para Determinação do Valor INTRínSECo das Armas de Fogo}

No que tange a classificação do estado das armas de fogo antigas ou obsoletas, nos Estados Unidos e em alguns países europeus, determinadas entidades ligadas a atividades de colecionismo, preservação e manutenção elaboram parâmetros de análise para a classificação de tais peças. No Brasil, entretanto, ainda não há um parâmetro confiável a ser seguido ou uma norma institucionalizada a respeito do tema.

$\mathrm{Na}$ maioria dos sistemas adotados internacionalmente, é levado em conta o grau de originalidade do acabamento, a existência de marcas de prova, números de série, peças originais ou números de patentes. Os parâmetros elaborados pela National Rifle Association of America - $N R A^{5}$, por exemplo, estão entre os mais adotados por colecionadores de armas e museus que se dedicam a abriga-las em seu acervo.

Supica (1996) apresenta um método para a caracterização do valor de armas de fogo (antigas e modernas) que consiste na reunião de dois fatores: valor intrínseco e valor histórico ${ }^{6}$. Desse modo, o primeiro corresponde ao valor da arma de fogo em $\mathrm{si}^{7}$, conforme o estado físico no qual se apresen-

4 Art. 65. As armas de fogo, acessórios ou munições mencionados no art. 25 da Lei no 10.826, de 2003, serão encaminhados, no prazo máximo de quarenta e oito horas, ao Comando do Exército, para destruição, após a elaboração do laudo pericial e desde que não mais interessem ao processo judicial.

5 A National Rifle Association of America (Associação Nacional de Rifles da América) é uma associação norte-americana, fundada em 1871, sem fins lucrativos, com sede atual em Fairfax, no Estado da Virgínia, que se dedica à salvaguarda dos princípios estabelecidos pela segunda emenda constitucional dos Estados Unidos (Second Amendment)e à promoção dos direitos dos proprietários de armas de fogo, colecionadores e praticantes da caça legalizada.

6 No original, intrisic value e historic value.

7 Neste trabalho acataremos a definição de arma de fogo conforme adotado pela legislação brasileira, tal como "arma propriamente dita", armas de arremesso complexas que utilizam, para expelir seus projéteis, a força expansiva dos gases resultantes da combustão da pólvora. 
ta; por sua vez, o segundo é definido mediante a correspondência da arma de fogo com um evento ou personalidade histórica, a partir da qual seria possível julgar a "significação histórica"

Nesta pesquisa, não temos a intenção de aprofundar a discussão sobre o valor intrínseco das armas de fogo, tendo em vista que nosso objetivo é tão somente problematizar o conceito de "valor histórico" atualmente admitido para a avaliação do armamento entregue na Campanha de Desarmamento. Entretanto, segue abaixo um quadro de referência dos critérios adotados pela $\mathrm{NRA}^{9}$ quanto ao valor intrínseco das armas, tendo em vista que será útil para a compreensão do método adotado por aquela associação.

Tabela 1 - Critérios adotados pela NRA quanto ao valor intrínseco das armas

\begin{tabular}{|c|l|}
\hline CONDIÇÃO & \multicolumn{1}{|c|}{ CARACTERIZAÇÃO } \\
\hline DE FÁBRICA & $\begin{array}{l}\text { Todas as peças originais, acabamento 100\% original e abrangendo } \\
100 \% \text { da superfície total da arma, estado de aparência impecável, estado } \\
\text { "mint", por dentro e por fora, absolutamente sem detalhes. }\end{array}$ \\
\hline EXCELENTE & $\begin{array}{l}\text { Todas as peças originais, cerca de } 80 \% \text { do acabamento original, sem fer- } \\
\text { rugem e corrosão, marcações nítidas e profundas, número serial bem } \\
\text { visível, desenhos existentes na madeira e metal perfeitos, zigrinado nas } \\
\text { talas e coronhas sem danos, raiamento perfeito. }\end{array}$ \\
\hline MUITO BOA & $\begin{array}{l}\text { Todas as peças originais, cerca de 30\% a 40\% do acabamento original, } \\
\text { sem ferrugem e corrosão, marcações nítidas mas não tão profundas, nú- } \\
\text { mero serial visível, desenhos existentes na madeira e metal perceptíveis, } \\
\text { zigrinado nas talas e coronhas com poucos danos, quinas vivas, marcas } \\
\text { originais de ferramental visíveis, raiamento aceitável. }\end{array}$ \\
\hline BOA & $\begin{array}{l}\text { Algumas peças de menor importância reparadas ou refeitas, acaba- } \\
\text { mento original inexistente ou reoxidação feita com processo similar } \\
\text { ao da época, algumas marcas de corrosão e "pittings", marcações ainda } \\
\text { legíveis, número serial legível, desenhos existentes na madeira e metal } \\
\text { desgastado, madeira restaurada e reinvernizada, zigrinado nas talas e } \\
\text { coronhas desgastados, pequenos riscos e batidas nas peças de madeira, } \\
\text { quinas levemente arredondadas, raiamento não aceitável. }\end{array}$ \\
\hline
\end{tabular}

8 No original: historical significance.

9 Os critérios foram traduzidos por Carlos F. P. Neto, membro vitalício da NRA, e publicados no portal armasonline.org. 
Tabela 1 - Critérios adotados pela NRA quanto ao valor intrínseco das armas (continuação)

\begin{tabular}{|c|l|}
\hline CONDIÇÃO & \multicolumn{1}{|c|}{ CARACTERIZAÇÃO } \\
\hline RUIM & $\begin{array}{l}\text { Várias peças reparadas ou refeitas, acabamento original inexistente, } \\
\text { oxidação refeita, mas com processo não condizente com o da época, } \\
\text { diverssas marcas de corrosão e "pittings", marcações ilegíveis, número } \\
\text { serial legível, desenhos existentes na madeira e metal bem desgastados, } \\
\text { madeira restaurada e re-envernizada e possivelmente reparada por que- } \\
\text { bras, zigrinado nas talas e coronhas desgastados, quinas arredondadas, } \\
\text { raiamento inexistente. }\end{array}$ \\
\hline PÉSSIMA & $\begin{array}{l}\text { Várias peças quebradas, reparadas ou refeitas, acabamento original ine- } \\
\text { xistente e em péssimas condições, corrosão e "pittings" generalizados, } \\
\text { sem marcações legíveis, número serial inexistente ou apagado, desenhos } \\
\text { existentes na madeira e metal desgastados, madeira quebrada ou restau- } \\
\text { rada mas em condições improvisadas, zigrinado nas talas e coronhas } \\
\text { inexistentes, quinas arredondadas, raiamento inexistente; arma meca- } \\
\text { nicamente fora de operação, totalmente indesejada por colecionadores. }\end{array}$ \\
\hline
\end{tabular}

Fonte: NRA in: armasonline.org

Tais condições e critérios foram originalmente publicados no famoso livro de referência The Blue Book of Gun Values, de S. P. Fjestad, editado anualmente pela NRA ${ }^{10}$. Posteriormente, Jim Supica e Richard Nahas, na obra Standard Catalog of Smith \& Wesson (F+W Media Editor), aperfeiçoaram as definições da NRA, de modo a introduzir duas modificações:

- A nomenclatura "CONDIÇÃO DE FÁBRICA" foi substituída por "NOVA, NA CAIXA OU COMO NOVA". Segundo a nova classificação, armas em tais condiçóes devem apresentar a mesma condição de quando a arma saiu da fábrica, com itens originais: caixa, manuais e acessórios.

- Introdução de tabelas de percentuais de originalidade para a identificação do valor intrínseco da arma. Tais índices levam em consideração a preservação do acabamento original, de acordo com a idade do armamento. Os percentuais foram aplicados às armas com o acabamento oxidado ou niquelado ${ }^{11}$, classificadas nas condições "EXCELENTE", "MUITO BOA" e "BOA", conforme consta na Tabela 2.

10 É possível citar como referências similares as seguintes publicações: Flayderman's Guide to Antique American Arms, Standard Catalog of Firearms, Standard Catalog of Military Firearms, além de catálogos específicos das fabricantes Winchester, Luger, Smith \& Wesson, Remington, dentre outros.

11 Devido à durabilidade do acabamento, as armas de aço inoxidável mais utilizadas são encontradas em excelentes condições, o que levou o autor a não considerá-las na sua classificação. 
Tabela 2 - Percentual de originalidade de caracterização EXCELENTE

\begin{tabular}{|c|c|c|}
\hline ÉPOCA DE FABRICAÇÃO & ARMAS OXIDADAS & ARMAS NIQUELADAS \\
\hline PÓS-1945 & $98 \%$ & $99 \%$ \\
\hline $1920-1945$ & $95 \%$ & $98 \%$ \\
\hline $1890-1920$ & $90 \%$ & $95 \%$ \\
\hline $1865-1890$ & $85 \%$ & $90 \%$ \\
\hline PRÉ-1865 & $80 \%$ & $85 \%$ \\
\hline
\end{tabular}

Fonte: NRA in: armasonline.org

De modo geral, na condição de EXCELENTE, as armas possuem a configuração de peças original, bem como as marcações de fábrica. Devem, portanto, apresentar acabamento com, no mínimo, $80 \%$ do percentual de originalidade.

Tabela 3 - Percentual de originalidade de caracterização MUITO BOA

\begin{tabular}{|c|c|c|}
\hline ÉPOCA DE FABRICAÇÃO & ARMAS OXIDADAS & ARMAS NIQUELADAS \\
\hline $1920-1945$ & $90 \%$ & $95 \%$ \\
\hline $1890-1920$ & $70 \%$ & $80 \%$ \\
\hline $1865-1890$ & $50 \%$ & $70 \%$ \\
\hline PRÉ-1865 & $30 \%$ & $50 \%$ \\
\hline
\end{tabular}

Fonte: NRA in: armasonline.org

Uma arma classificada como MUITO BOA deve possuir todas as peças originais ou com alterações mínimas durante o período de uso. Deve ainda apresentar acabamento com, no mínimo, 30\% do percentual de originalidade.

Tabela 4 - Percentual de originalidade de caracterização BOA

\begin{tabular}{|l|l|}
\hline ÉPOCA DE FABRICAÇÃO & PERCENTUAL \\
\hline PÓS-1945 & $85 \%$ \\
\hline $1920-1945$ & $60 \%$ \\
\hline $1890-1920$ & $40 \%$ \\
\hline $1865-1890$ & $10 \%$ \\
\hline PRÉ-1865 & MENOS DE 10\% \\
\hline
\end{tabular}

Fonte: NRA in: armasonline.org

Por seu turno, uma arma classificada como BOA deve possuir a maior parte das peças originais ou algumas substituições de peças que não afetam o aspecto original, além de marcações visíveis. $\mathrm{O}$ acabamento 
deve preservar, no mínimo, $10 \%$ do percentual de originalidade. Nesse nível, a diferença entre o acabamento oxidado e niquelado, exigida nos níveis anteriores, não é significativa.

É importante ressaltar que esta classificação representa uma tentativa de descrever o estado geral de uma arma de fogo conforme as condições estabelecidas no sistema PPGS ${ }^{12}$, adotado pela NRA. A variação de um único aspecto de qualquer condição não exclui necessariamente a arma de determinada classificação.

Exemplo: uma arma que, em algum momento, apresentou a condição de EXCELENTE, em outra avaliação poder não ser rebaixada à condição de BOA somente por apresentar algum dano superficial ao material. No entanto, uma descrição responsável de qualquer arma vai mencionar qualquer variação do padrão de definição para a avaliação da condição, e qualquer variação provavelmente irá afetar o valor intrínseco.

A maioria dos colecionadores de armas do início e meados do século XX considera que, para definir uma arma como na CONDIÇÃO DE FÁBRICA, uma estimativa mais precisa do acabamento original é essencial. A alteração entre um grau $98 \%$ e $99,5 \%$ de uma pistola pode fazer uma diferença significativa em termos de valor, especialmente em exemplares raros, de séries especiais.

\section{Determinação do Valor Histórico das Armas de Fogo}

Quanto à atribuição de "valor histórico" às armas de fogo, trata-se da adição de importância histórica ao valor intrínseco da arma. É a posse comprovada da arma de fogo por uma personalidade reconhecida ou seu uso em determinado evento histórico. Tal valoração é subjetiva, uma vez que se remete à problematização do conceito de "valor histórico" na historiografia atual.

12 PPGS: sigla de Photo Percentage Grading System, sistema adotado pela NRA, com base em um banco de dados de imagens, para avaliar as condiçóes físicas das armas de fogo, com base no percentual de originalidade, obtido a partir da comparação do estado atual da arma apresentada e as características originais definidas pelas fabricantes. 
No sistema proposto por Supica (1996), a atribuição de valor histórico às armas de fogo leva em consideração duas variáveis: "significação histórica" e "credibilidade". A primeira, mais subjetiva, sempre dependerá do interesse do avaliador ou da instituição que solicita a avaliação. A segunda, por sua vez, se caracteriza pela busca de indícios objetivos que associem a arma de fogo a determinada pessoa ou evento histórico.

A primeira variável consiste em relacionar a arma de fogo a um determinado indivíduo famoso, personagem histórica ou autoridade reconhecida. Tal variável fornece um aumento considerável ao valor histórico da arma de fogo se esta estiver relacionada a personalidades políticas, militares, diplomáticas ou mesmo criminosos famosos, desde que se disponha de quantidade razoável de informações para associar a arma ao indivíduo em questão. O que se busca, portanto, é a associação da arma à fama ou notoriedade de determinado indivíduo.

O museu da NRA, em Fairfax, Virgínia, possui algumas peças associadas a determinadas personagens históricas. Um exemplo é a pistola FN 1900 Pocket (Figura 1), com cabo de madrepérola que teria pertencido a Theodore Roosevelt (que era membro vitalício da associação). Tal peça teria sido mantida pelo presidente norte-americano, notório apreciador de armas de fogo, durante muitos anos, na cabeceira de sua cama, na Casa Branca.

Por sua vez, o revólver Colt, calibre 32, cano longo (Figura 2), com o qual o presidente Getúlio Vargas cometeu suicídio, na noite de 24 de agosto de 1954, está exposto no Museu da República, no Rio de Janeiro. A arma foi incorporada à coleção do museu (sediado no antigo Palácio do Catete, onde ocorreu a fatalidade), em 1998, após doação da neta de Getúlio, Celina Vargas do Amaral Peixoto. 


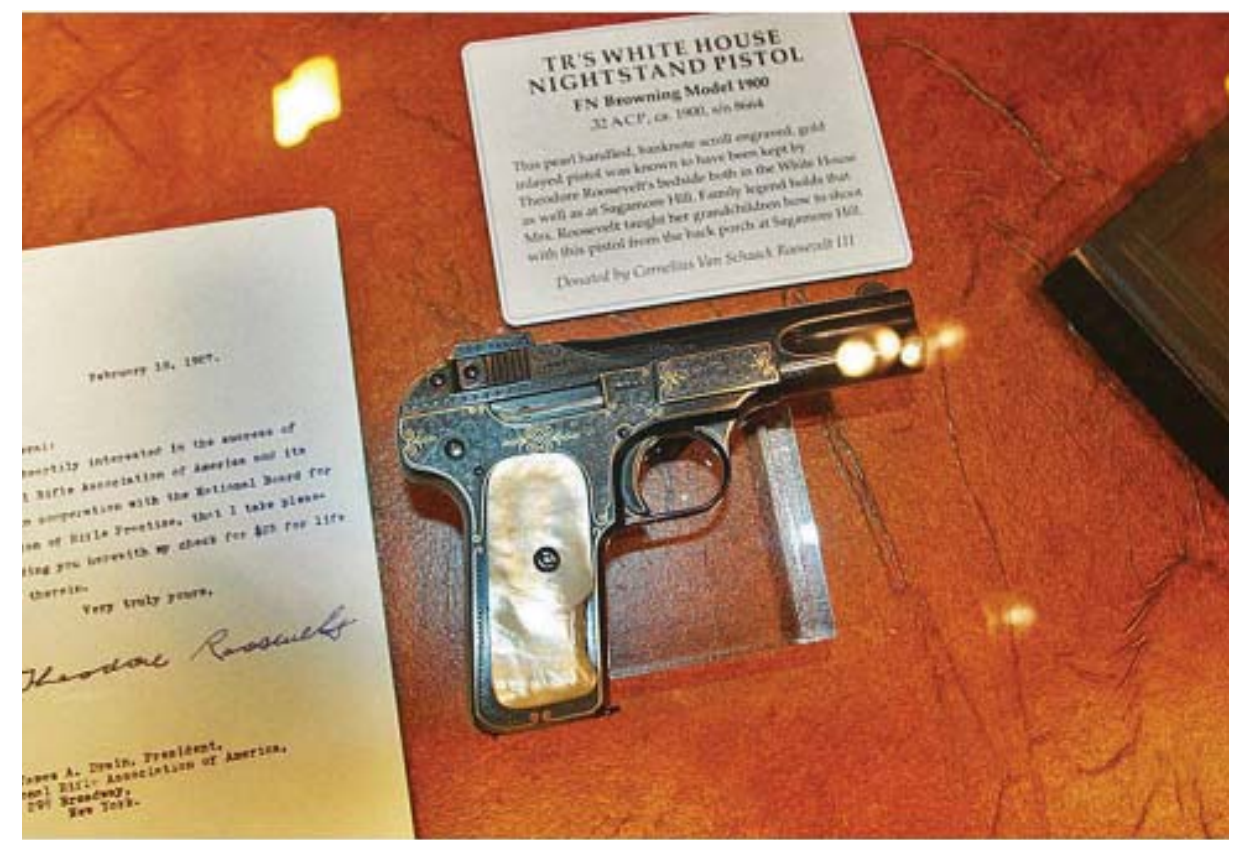

Figura 1 - Pistola FN Pocket que teria pertencido a Theodore Roosevelt. Fonte: Museu RNA.

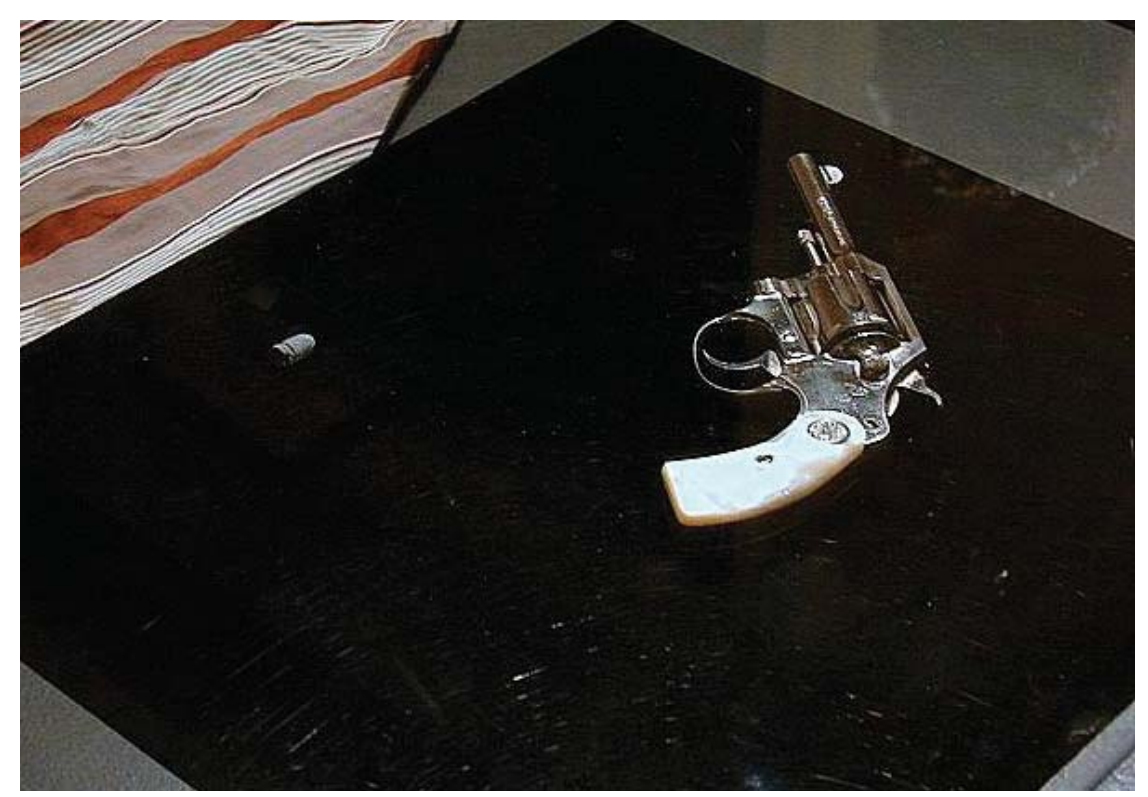

Figura 2 - Revólver Colt, calibre 32, cano longo, utilizado por Getúlio Vargas no seu suicídio. Fonte: Museu da República - RJ 
Não obstante, além da raridade da peça, uma arma de fogo ainda pode ter seu valor histórico relacionado ao seu uso em determinado evento histórico, de repercussão regional, nacional ou mundial. Exemplo é a espingarda C 1800 (Figura 3), com acabamento personalizado, presenteada por Napoleão Bonaparte ao Marquês Faulte de Vanteaux de Limoges, general de seu exército. A arma está exposta no museu da NRA, na cidade americana de Springfield, Massachusetts.

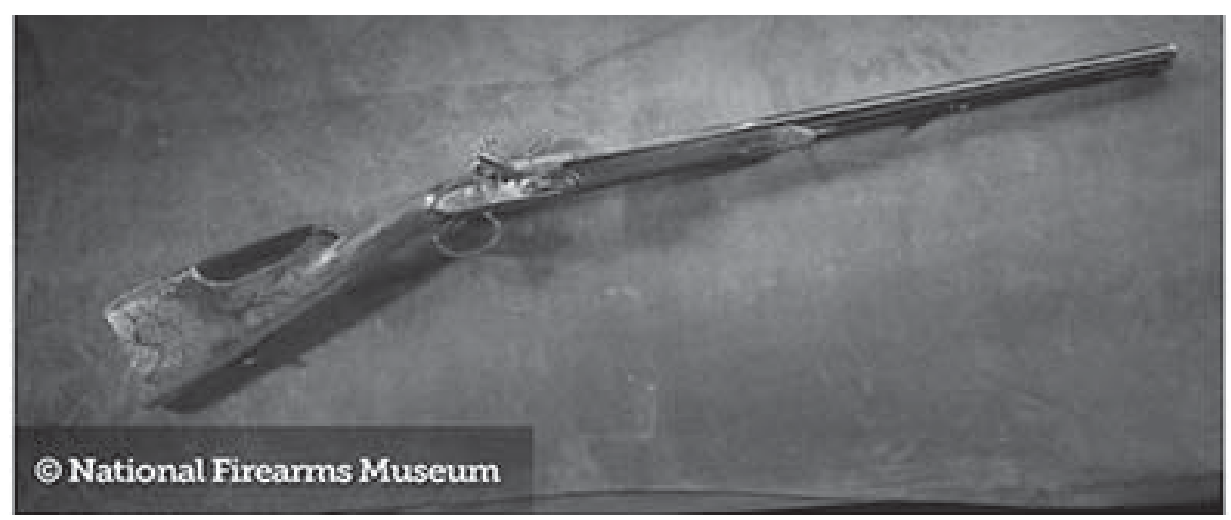

Figura 3 - Espingarda C 1800, presenteada por Napoleão Bonaparte ao Marquês Faulte. Fonte: Museu RNA.

Outro exemplo, desta vez no cenário nacional, é o fuzil "Chuchu" (Figura 4), arma utilizada pela Força Pública da Bahia, entre 1891 e 1897. Segundo de Mello (2007, p. 318):

Um senhor A. Chuchu, da Babia, obteve na Inglaterra, por intermédio de certo $H \mathrm{H}$. Lake, a 12 de agosto de 1884, patente sobre pistola de percussão anular e quatro canos basculantes que inventara [...] Em 1891patenteou um fuzil de tiro singular para a policia de seu Estado.

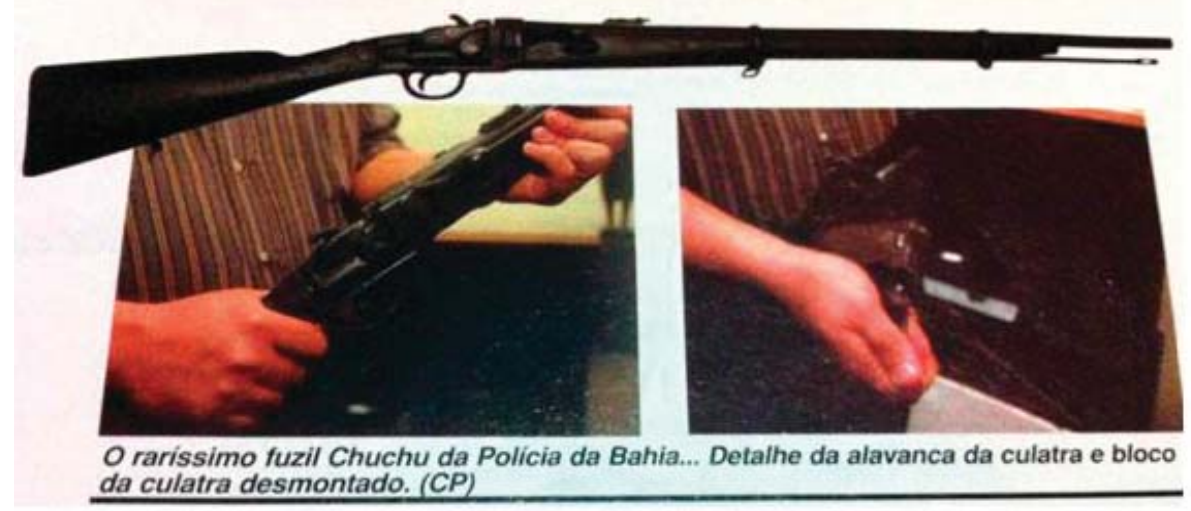

Figura 4 - Fuzil "Chuchu” da Polícia da Bahia.

Fonte: Revista Magnum Nov/dez 1997. 
Tal arma, segundo o historiador, era muito apreciada pelos seguidores de Antônio Conselheiro, que a tomavam como rival ao fuzil Comblain. Os exemplares do fuzil utilizado na Guerra de Canudos são raríssimos, sendo possível apreciar um deles exposto no Museu da Polícia Militar da Bahia.

Serão necessárias sólidas evidências para sustentar a ligação direta ou indireta do armamento com um evento histórico. Nesse sentido, as informações disponíveis nos diversos meios de comunicação são extremamente úteis para a avaliação criteriosa da relação entre arma de fogo e evento histórico.

Podem ser adotados como referências: publicações especializadas, reportagens, documentos oficiais, manuais, boletins militares, correspondências, registros de família, inventários. Também são aceitos como meios de prova fotografias, registros audiovisuais, dentre outros mecanismos de consulta essenciais para tal fim.

A segunda variável está diretamente relacionada ao que já foi dito anteriormente: consiste na análise objetiva das informações disponíveis, nos mais diversos meios, para autenticar a proveniência da arma de fogo. SUPICA (1996) subdividiu os critérios de credibilidade em cinco níveis, dispostos na tabela seguinte.

Tabela 5 - Critérios de credibilidade.

\begin{tabular}{|c|c|c|}
\hline NÍVEL & CARACTERÍSTICA & $\begin{array}{c}\text { VALOR HISTÓRICO } \\
\text { ATRIBUÍDO }\end{array}$ \\
\hline A & CERTO & $100 \%$ \\
\hline B & PROVÁVEL & $75 \%$ a $50 \%$ \\
\hline C & PLAUSÍVEL & $50 \%$ A $25 \%$ \\
\hline D & QUESTIONÁVEL & $25 \%$ A $5 \%$ \\
\hline E & IMPOSSÍVEL & $0 \%$ \\
\hline
\end{tabular}

Fonte: SUPICA (1996).

É desnecessário afirmar que tais índices possuem caráter subjetivo, aproximativo, tendo em vista o revisionismo do próprio conceito de "valor histórico" na historiografia atual. Contudo, a divisão em níveis permite que a formalização de um padrão minimamente aceitável para aferição da possibilidade de ocorrência valor histórico nas armas de fogo recebidas na Campanha de Desarmamento. 
De acordo com a escala, para alcançar o nível A, uma arma de fogo deve proporcionar um alto grau de certeza de que ela realmente pertenceu a uma personalidade histórica ou está associada a um evento. Deve, portanto, conforme a exigência do padrão, ser acompanhada de ampla documentação que satisfaça os seguintes critérios:

a) Oportunidade: os indícios deverão pertencer ao período histórico ao qual a arma está supostamente associada.

b) Pronta identificação: os indícios devem identificar especificamente a arma. Na maioria das vezes isso é feito pelo número de série, marcas de prova, brasões, inscrições, etc. Contudo, de acordo com Supica (1996), "ocasionalmente, é possível que fotografias ou a descrição das características físicas únicas e específicas satisfaçam tal critério", porém tal abordagem requer extremo cuidado.

c) Credibilidade da fonte: a pronta identificação descrita no item anterior deve considerar a credibilidade da fonte. Nesse sentido, o documento que atesta com maior credibilidade a proveniência das armas de fogo são os factory records ${ }^{13}$. Não obstante, certificados de propriedade, documentos oficiais (autenticados), registros pessoais, também podem ser admitidos como indícios para atendimento da exigência de credibilidade.

As armas do nível $\mathrm{B}$ também têm um número avançado de possibilidades quanto à atribuição do valor histórico. Muito embora não requeiram o grau de confiabilidade de indícios exigidos pelas armas de nível A, necessitam de ampla documentação para comprovação de sua significação histórica.

Assim, uma arma classificada nesse nível deve estar acompanhada de indícios secundários, que não pertençam necessariamente ao período histórico ao qual está vinculada, mas que se tratem de fontes críveis. Exemplo disso é uma arma de fogo que supostamente pertencera a uma personalidade histórica que apresentou a um amigo e que, décadas depois, foi adquirida por um colecionador em um leilão. Um bilhete de época autenticado pode ser um forte indício quanto à proveniência de tal arma.

13 Factory record (registro de fábrica) passou a ser um termo genérico que significa uma carta de uma autoridade reconhecida com base em uma pesquisa de registros originais do fabricante da arma quanto à disposição de uma arma da fábrica. É uma das mais poderosas ferramentas disponíveis para pesquisar a autenticidade da atribuição histórica de uma arma. Em circunstâncias ideais ela deve apresentar a data em que foi fabricada, a configuração da arma (acabamento, comprimento do cano, calibre, etc), e qualquer característica especial. 
As armas classificadas no nível C estão entre a maioria das armas cujos detentores alegam possuir “valor histórico”. Para Supica (1996, p. 05), frequentemente, a apresentação desse tipo de material vem acompanhada de afirmações tais como: "Esta arma pertencia a fulano de tal" ou "Esta arma é da batalha travada em..." Todavia, embora o relato oral seja frequentemente reivindicado como fonte de credibilidade, tais armas podem vir acompanhadas de alguns documentos, como fotografias, por exemplo,

Barreiros Jr. (2003, p. 19) reforça a tese de que o valor de uma arma de fogo deve ser ampliado "pelo fato de ela ter pertencido a alguém famoso, ou por ter sido utilizada em algum evento de destaque”. Não obstante, o autor admite, através de uma série de exemplos que advém da sua experiência como avaliador de armas, que na Europa e nos Estados Unidos os critérios para atribuição de valor histórico são mais bem definidos que no Brasil. Desse modo, para o autor:

Somente provas inequivocas como cartas próprias de fábricas atestando o envio de determinada arma a alguém famoso, documentos de controle de armamentos de unidades militares, fotos claras com determinada arma sendo portada em um dado momento histórico podem, realmente agregar valor a uma peça. (BARREIROS JR, 2003, p. 20)

Na sequência da tabela, as armas de nível D são aquelas que sempre vêm acompanhadas de afirmações dos proprietários "auto-testemunhando" sua autenticidade, em razão de "ter visto uma foto" ou "ouvido de alguém uma história”. O fato é que as armas classificadas nesse nível se distanciam cada vez mais de um critério confiável quanto à sua credibilidade.

Por último, as armas de nível E são aquelas que não apresentam nenhum indício confiável de sua proveniência. Nessa categoria estão as armas que, somente pelo fato de ser antigas, são imediatamente identificadas como sendo "da Segunda Guerra Mundial”, pertencentes ao "cangaço", etc. Nesses casos, uma análise do valor intrínseco bastará para identificar a ausência de significação histórica do armamento.

Métodos análogos ao exposto acima podem proporcionar uma melhor avaliação do "valor histórico" das armas de fogo antigas e/ou obsoletas. Atualmente, é fundamental que as instituições envolvidas no recebimento de armas entregues na Campanha Nacional do Desarmamento disponham de tais mecanismos como veículos facilitadores de trabalho. 


\section{O Problema do Procedimento Adotado no Brasil}

É possível, portanto, destacar os principais problemas decorrentes do atual procedimento adotado pela Polícia Federal, em conjunto com o Exército Brasileiro, no que tange ao recebimento, processamento e destruição das armas de fogo. A seguir, com base na sistemática adotada pela NRA, apresentaremos algumas questóes e as principais deficiências de tal procedimento em vigor.

O primeiro ponto a ser considerado trata-se da recomendação constante do Memorando-Circular no 09/2011-DARM/DICOR/DPF. Segundo o exposto no documento, as armas de fogo que podem, eventualmente, possuir "valor histórico", devem ser submetidas "a simples exame de constatação, instruído com fotos do armamento, onde se indiquem os elementos de conviç̧ão" (grifo meu).

Como se percebe, no exame de uma arma de fogo, para uma aferição aproximada de seu valor histórico, estão em jogo duas variáveis: significação histórica e credibilidade. Esta última ainda leva em conta outros fatores como oportunidade, pronta identificação e credibilidade da fonte.

Desse modo, na avaliação são considerados elementos de ordem subjetiva e objetiva que ultrapassam as limitações impostas por um simples exame de constatação instruído com fotografias. A despeito de não ficar claro o que a norma caracteriza como "simples exame", ainda que tal arma seja submetida a exame pericial para identificação de suas características, ainda assim tal exame se limitará a, no máximo, atestar o valor intrínseco da arma de fogo, jamais seu valor histórico.

Não há, portanto, como indicar "elementos de convicção" do valor histórico da arma de fogo sem se levar em consideração, por exemplo, uma avaliação dos critérios dispostos nas tabelas 1 e 4 . O procedimento descrito no memorando expedido pela Polícia Federal limita-se à análise superficial da arma propriamente dita, além do que, não exige qualquer indício material para a associação da arma de fogo a uma personalidade ou evento histórico. 
Outro ponto discutível trata-se da orientação segundo a qual a análise preliminar do valor histórico das armas de fogo entregues deve obedecer aos critérios constantes do Projeto de Lei $n^{\circ}$ 1782/07. O texto da referida proposta determina quais armas devem ser consideradas passíveis de atribuição de valor histórico:

Todas as armas com brasão ou inscrição Colonial, Imperial ou da República, ou qualquer sinal que indique seu uso oficial, inclusive em estados e municípios [...] Aquelas que tenham sido empregadas pelas Forças Armadas ou Auxiliares do Brasil, ou tenham sido trazidas como troféus de guerra de hostilidades em que a Nação tenha participado, tenham participado de conflitos internos ou outros eventos da história do Pais ou tenham pertencido a personalidades históricas brasileiras ou estrangeiras (BRASIL, 2007, p. 02).

Pelos critérios anteriormente expostos na metodologia adotada pela NRA, a atribuição de valor histórico a armas de fogo obedece a uma escala cujos níveis determinam a possibilidade maior ou menor de valoração, conforme a articulação de duas variáveis específicas: significância histórica e credibilidade. O texto do referido projeto de lei apresenta-se de forma genérica, levando em consideração, inclusive, qualquer arma brasonada, com brasão dos períodos colonial, imperial ou republicano.

O texto não especifica a necessidade de vinculação da arma de fogo a um evento histórico de reconhecida importância na historiografia oficial, mediante a necessidade de indícios confiáveis para a comprovação da proveniência. Ademais, ao se admitir qualquer sinal que indique o uso oficial como elemento indicativo de valor histórico, é possível abstrair, inclusive, o juízo absurdo de que qualquer arma brasonada o possui.

Nesse sentido, é necessário repensar o papel que o IPHAN, órgão vinculado ao Ministério da Cultura que apresenta a missão de preservar o patrimônio cultural brasileiro, exerce quanto ao tema. Ressalte-se que o IPHAN possui a função de tutela dos bens materiais e imateriais que compõem patrimônio histórico e cultural do país, dentre eles os artefatos bélicos associados a personagens e eventos históricos do Brasil. 
A juíza federal Elisabeth Leão, ao julgar Ação-Civil Pública, com pedido de tutela antecipada interposta pelo Instituto do Patrimônio Histórico, expediu intimação ao IPHAN, para que informasse ao Juízo sobre a existência de "interesse e condições para atestar o valor cultural histórico das armas entregues à Polícia Federal na Campanha do Desarmamento" (BRASIL, 2010a, p. 03).

A intimação decorre do entendimento da magistrada segundo o qual, não obstante, por força de lei, ao Comando do Exército caiba estabelecer normas específicas para a definição do valor histórico das armas de fogo, o IPHAN, "responsável pelo trabalho de identificação, documentação, proteção e promoção ao patrimônio cultural brasileiro, poderia confirmar o caráter histórico e cultural dessas armas de fogo" (BRASIL, 2010a, p. 04). Em contato com o Instituto, inquirimos acerca da existência de alguma instrução ou norma técnica sobre o tema, porém, até o momento da conclusão deste artigo, não obtivemos resposta.

Ao deferir a tutela antecipada, a juíza ressaltou a "inegável importância da preservação do patrimônio histórico cultural, não só no Brasil, mas em todos os países, inclusive no tocante às armas de fogo" (BRASIL, 2010a, p. 04). Para tanto, a magistrada destaca a existência de diversos museus nacionais e estrangeiros que possuem no acervo armas de fogo de interesse histórico.

No Brasil, podemos citar como exemplo o Museu Histórico Nacional - MHN, onde é possível encontrar algumas peças tais como revólveres, pistolas, mosquetes, carabinas, arcabuzes e até canhões, associados a personagens históricas ou a algum evento histórico. No arsenal do museu, os visitantes podem se deparar com um mosquetão Minié, utilizado por tropas de artilharia do Exército Brasileiro na Guerra do Paraguai ou com a Pistola Colt 1911, exclusiva do Exército Americano, presenteada pelo presidente Teddy Roosevelt ao marechal Rondon, na famosa expedição pelo interior do Brasil, na década de 1910.

Mantivemos contato com o Departamento de Acervo - DEDAC, do Museu Histórico Nacional, no intuito de averiguar a existência de procedimento ou norma técnica ou instrução adotada como referência para determinar o valor histórico dos itens que compõem a seção de armas de fogo. Em resposta, o referido departamento afirmou que promove avaliações periódi- 
cas do valor de todo seu acervo, incluindo as peças da coleção de armaria, a partir de catálogos de leilóes nacionais e de outros países, bem como realizando consultas a especialistas (pesquisadores).

Segundo a responsável pela seção do museu, também é levado em conta o histórico da peça: se foi doada ou comprada, quais são os materiais componentes, os valores anteriores; participação em exposições, citação em bibliografia especializada, etc. Do mesmo modo, é verificada existência de peças similares em outros museus, além de outros fatores que podem influenciar no valor final da peça.

Na oportunidade, a funcionária afirmou desconhecer a existência de alguma norma técnica ou instrução, indicada pelo IPHAN, Ministério da Cultura ou outro órgão, que o museu tenha seguido em algum momento para padronizar a avaliação das peças. Quanto à datação, foi informado que, de maneira geral, tal informação é obtida no momento de entrada do acervo no museu. Caso não seja possível, os técnicos realizam pesquisas para determinar o maior número possível de informações: data, fabricante, local onde foi utilizada, proprietário.

Desse modo, fica claro que, muito embora o museu promova um excelente esforço para identificação e atribuição de valor histórico às armas de fogo que constituem seu acervo, a instituição ainda carece de uma norma específica e detalhada sobre o tema. A falta de critérios normativos padronizados torna a análise uma tarefa complexa e de difícil solução.

\section{Conclusã̃o}

Atualmente a Polícia Federal e o Exército Brasileiro ainda não dispõem nos seus quadros de pessoal habilitado, com formação adequada para avaliação do valor histórico das armas de fogo entregues na Campanha de Desarmamento. Nesse sentido, com frequência, em tais situações, é necessário recorrer a especialistas ou entidades que possam executar serviços de avaliação do referido valor. 
Um exemplo é a Associação Brasileira dos Colecionadores de Armas - ABCA, que alega ser capacitada para fornecer laudos de identificação, avaliação, valor, obsolescência e valor histórico de armas antigas, assinados por museólogo especializado e economista e tem valor legal, para fins de colecionismo ou incorporação em acervos de museus ${ }^{14}$.

Desse modo, na ausência de entidades e profissionais que possam fornecer laudos de avaliação, a carência de uma norma específica para definição do termo "valor histórico" das armas entregues na Campanha de Desarmamento dificulta o trabalho a ser realizado em conjunto pelo Exército e Polícia Federal. Muito embora os padróes adotados pela NRA, esmiuçados ao longo deste trabalho, não possam ser aplicados rigorosamente no cenário brasileiro, podem ser plenamente adaptados para a formalização de critérios razoáveis para a aferição do valor histórico das armas. Para o historiador Jacques Le Goff:

A memória, onde cresce a história, que por sua vez a alimenta, procura salvar o passado para servir o presente e o futuro. Devemos trabalhar de forma que a memória coletiva sirva para libertação e não para a servidão dos homens. (LE GOFF, 1994, p. 477).

A falta de uma norma, além de prejudicar a avaliação sobre o valor histórico das armas de fogo, compromete a preservação do patrimônio histórico brasileiro. É preciso que seja evitada a destruição indiscriminada do armamento arrecadado na Campanha de Desarmamento, sinal de desapego à memória. As armas de fogo que tenham associado valor histórico a seu valor material devem ser preservadas para que as gerações posteriores possam dispor de indícios para a interpretação dos personagens e acontecimentos que construíram a história do País.

Dyêgo Marinho Martins

Historiador, Mestre em Cultura e Sociedade. Agente Administrativo, lotado na Superintendência Regional da Polícia Federal no Maranhão.

14 Disponível em: <http://www.armaria.com.br/abca/abcahp.htm>. Acesso em: 06/12/2013. Atualmente tal serviço encontra-se suspenso. 


\title{
Memory and Heritage: the issue of historical value of firearms delivered in disarmament campaign
}

\begin{abstract}
Research focused on the analysis of the problem about the criteria used to define the historical value of old and obsolete firearms, delivered in the National Campaign for Disarmament, established under Federal Law 10.826/2003 (Disarmament Statute). Through discussion on the regulation currently in force, intended to demonstrate the absence of a reliable standard for the definition of historical value. Therefore, it is presented a system adopted by the National Rifle Association, which considers variables such as historical significance and credibility associated with factors like opportunity, prompt identification and credibility of the source. Finally, it discusses how the absence of a detailed standard on the subject indicates carelessness with preservation of national memory and leads to the destruction of firearms that constitute the Brazilian historical heritage.
\end{abstract}

KEYWORDS: Disarmament. Federal Police. Brazilian Army. Firearms. Heritage.

\section{REFERÊNCIAS}

BRASIL. Câmara Federal. Projeto de Lei 1.782/07. Andreia Zito. Minuta. Brasília, 2007.

BRASIL. Decreto n 6.715. Diário Oficial da União, Brasília, DF, $29 / 12 / 2008$.

BRASIL. Estatuto do Desarmamento: lei n. 10.826, de 22 de dezembro de 2003. Brasília: Câmara dos Deputados, Coordenação de Serviços Gráficos, 2006.

BRASIL. Justiça Federal - Seção Judiciária do Estado de São Paulo. Ação Civil Pública no 0011559-16.2010.403.6100. Autor: Instituto do Patrimônio Histórico - IPH. Réu: União Federal. Relatora: Doutora Elizabeth Leão. Sentença, 10 jun. 2010 a.

BRASIL. Justiça Federal - Seção Judiciária do Estado de São Paulo. Agravo de Instrumento No 0027168-06.2010.4.03.0000/SP. Relator: Desembargador Federal Carlos Muta. Acórdão de 29 set. 2010 b.

BRASIL. Ministério da Justiça. Departamento de Polícia Federal. Memorando-Circular no 09/2011-DARM/DICOR/DPF. Brasília, 2011 
DE MELLO, Frederico P. A Guerra Total de Canudos. São Paulo: A Girafa, 2007.

LE GOFF, Jacques. “Memória”. In: História e Memória. Campinas: Ed. UNICAMP, p. 423-483, 1994.

NETO, Carlos F P. Restauração, conservação e avaliação de armas novas e antigas. Disponível em: http://armasonline.org/armas-on-line/. Acesso: 20/09/2013.

Magnum, 55. Year 10, nov/dec, 1997.

Magnum, 82. Year 13, jan/feb, 2003.

SUPICA, JIM. Pieces of History: a system for evaluating historically attributed firearms. In: FJESTAD, Steven. The Blue Book of Gun Values $17^{\text {th }}$ edition.Minnesota: Blue Book Publications, 1996.

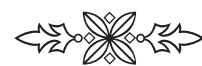

